ROCZNIKI PEDAGOGICZNE

Tom 13(49), numer 4 - 2021

DOI: http://doi.org/10.18290/rped21134.10

GRAŻYNA GAJEWSKA

\title{
TROSKA O DZIECKO TROSKĄ O JEGO OPIEKUNÓW. PIECZA ZASTĘPCZA I ADOPCJA W WARUNKACH PANDEMII. PORÓWNANIE WYNIKÓW SONDAŻY 2021 I 2009
}

\author{
1. TROSKA O DZIECKO TROSKĄ O JEGO OPIEKUNÓW - \\ WPROWADZENIE. CZYLI DLACZEGO W WARUNKACH PANDEMII \\ SZCZEGÓLNIE WAŻNE JEST ZADBANIE TAKŻE O OPIEKUNÓW
}

Współczesne zjawiska społeczne, pedagogiczne, szczególnie te powstające w trwającej pandemii, poddawane są coraz częściej diagnozowaniu, które pozwala na weryfikację wiedzy naukowej na ich temat. Mało jest publikowanych analiz systemu wsparcia rodziny i pieczy zastępczej, szczególnie instytucjonalnej, a także opieki nad dzieckiem do lat trzech oraz oświatowych form / instytucji opieki i wychowania, np. świetlic, internatów czy burs szkolnych.

Każde dziecko musi mieć opiekuna. Bez niego osiągnięcie względnej samodzielności życiowej byłoby niemożliwe. Istotnego wymiaru nabiera więc to, jaki on powinien być i jaki jest, a w szczególności kim jest. We wskazanych kontekstach ważne jest np. rozumienie opiekuna spolegliwego T. Kotarbińskiego, który podkreśla, że:

„Opiekun wtedy jest spolegliwy, kiedy można słusznie zaufać jego opiece, że nie zawiedzie, że zrobi wszystko, co do niego należy, że dotrzyma placu w niebezpieczeństwie i w ogóle będzie pewnym oparciem w trudnych okolicznościach. Opiekunem będzie dla nas każdy, kto ma jako zadanie zadbać o kogoś poszczególnego lub o taką czy inną gromadę istot, pilnując takiego lub innego ich dobra" (Kotarbiński, 1976, s. 63-64).

Wskazując, że szczególnym darem dla dziecka jest troskliwy opiekun, niezmiernie ważnym zadaniem staje się jego jak najlepsze przygotowanie, wspieranie przy

Dr hab. GraŻYna GajewSKa, prof. UZ - Instytut Pedagogiki, Wydział Nauk Społecznych Uniwersytetu Zielonogórskiego; adres do korespondencji: ul. Licealna 9, 65-419 Zielona Góra; e-mail: G.Gajewska@ipp.uz.zgora.pl; ORCID: https://orcid.org/0000-0003-0242-5080 
wejściu i pełnieniu przez niego ról opiekuńczo-wychowawczych (por. Gajewska, 2006, 2020; Harewska, 2016, s. 18-21, Harewska, 2021, s. 102-128 oraz s. 381-392).

Warto podkreślić, że chodzi nie tylko o rodzica, rodziców biologicznych, ale w tej refleksji przede wszystkim o „opiekuna społecznego”, opiekuna prawnego, często profesjonalistę, którym może być osoba, osoby lub formy rodzinne i instytucjonalne (formalne i nieformalne). Nie sposób także pominąć roli rodziców chrzestnych. Wymienione grupy opiekunów oraz ich zmiana zadań, sytuacja, kształcenie na profesjonalistów, wsparcie i dopełnianie, zastępowanie w pandemii będą przedmiotem zainteresowań w podjętej w artykule refleksji.

Troska o dziecko wymaga nie tylko jak najlepszej dbałości o nie, ale także jego opiekunów, zarówno formalnych jak i nieformalnych, wynikającej z przejętej prawnej lub moralnej odpowiedzialności za to czy, jak i na ile włączają się w proces opieki nad nim, wtedy gdy ono samo nie może lub nie potrafi samodzielnie żyć (Gajewska, 2020).

Termin „troska o kogoś” ma bardzo wiele synonimów, takich jak: dbanie, doglądanie, dozór, kontrola, kontrolowanie czegoś, kontrolowanie kogoś, kuratela, nadzór nad czymś, opieka, opiekowanie się czymś, opiekowanie się kimś, piecza, pilnowanie, sprawdzanie, staranie, straż, strzeżenie czegoś, strzeżenie kogoś, troska o coś, troszczenie się (Słownik synonimów języka polskiego, pobrano 9.04.2021, https://synonim.net/inaczej-troska+o+kogoś). Jest podobnie także przy najczęściej stosowanych przez autorkę niniejszego artykułu pojęciach „opieka” lub „pomoc" - różnie w literaturze definiowanych. Nie jest tym samym co we wprowadzonym w ustawie o wsparciu rodziny i systemie pieczy zastępczej terminie „piecza nad dzieckiem”. „Troska” oznacza - jak zapisano w Wielkim słowniku języka polskiego - „dbanie o coś lub kogoś w taki sposób, że poświęca się temu dużo czasu i uwagi lub otacza opieką" (pobrano 9.04.2021, https://wsjp.pl/index. php?id_hasla=857\&id_znaczenia=4028520\&l=5).

Jak słusznie podkreślili A. Błasiak i W. Pasierbek: „im liczniejsze i większe są zagrożenia w świecie, tym bardziej aktualna staje się troska o innych, ale i o siebie" (Błasiak, Pasierbek, 2020, s. 5). Być może dlatego rodzice zastępczy rezygnują ze swoich zadań.

Istotnym elementem wypowiedzi będzie ukazanie wybranych wyników własnych badań podłużnych, dotąd nie publikowanych, wynikających z dbałości o kształcenie liderów jak najlepiej przygotowanych do roli opiekunów, wychowawców, edukatorów, nauczycieli. Od wielu lat ważne jest dla autorki prowadzenie także kampanii informujących społeczność akademicką o rodzinnej i instytucjonalnej pieczy zastępczej. Ich celem jest kształtowanie świadomości społecznej, w tym także gotowości studentów, szczególnie pedagogiki i słuchaczy studiów podyplomowych nadających uprawnienia tzw. przygotowania pedagogicznego do 
podejmowania i wspierania rodzicielstwa zastępczego i adopcyjnego (Gajewska, 2006, 2009a, 2009b, 2009c, 2020). Wychodzi ona z założenia, że „świadomość uwarunkowań zachowań prospolecznych sprawia, że ludzie zdaja sobie sprawe $z$ tego dlaczego nie pomagaja innym. Rezultat jest zaskakujacy: zwiększa to ich gotowość do działań na rzecz innych" (Gajewska, 2006, s. 24, Gajewska, 2009, s. 111; cyt. za Aronson, Wilson, Akert, 1997, s. 493).

Powyższe słowa są istotne w przygotowaniu kadry, która będzie właściwie rozumiała specyfikę bycia dobrym opiekunem, pomocnikiem, wychowawcą i dobrze tworzyła, modyfikowała rzeczywistość społeczną i zostanie jak najlepiej wyposażona w wiedzę na ten temat, a także kompetencje i umiejętności do - być może - podjęcia się roli rodzica zastępczego.

Nadal także rzadko podkreśla się i dobrze realizuje współdziałanie na rzecz dziecka wszystkich jego opiekunów i osób wspierających formalnie tworzących różne systemy, m.in.: rodzinne, oświatowe (szczególnie wynikające z obowiązkowej edukacji dziecka), zdrowia, sądownictwa, bezpieczeństwa narodowego.

„W służbie dziecku” jest więc troska o jego dobro. Niestety w pandemii nastąpiło wiele zmian w systemowej działalności społecznej dla dziecka i jego rodziny. Powstała nowa sytuacja, z często pojawiającymi się nagłymi, skrajnymi, licznymi i niespodziewanymi zmianami egzystencji opiekunów i ich rodzin, a także sprawowanej opieki, wychowania i edukacji oraz wsparcia i pomocy. Odkrywane są słabe „ogniwa” systemu czy podsystemów, szczególnie oświatowego, pomocy społecznej, zdrowia, czy sądownictwa, ale także - co jest ciekawe poznawczo ujawniane są ich zasoby i nowe możliwości.

Troską o dziecko jest także, a może przede wszystkim społeczne wsparcie rodziny. Trudno bowiem podważyć stwierdzenie, że „Prawidłowo funkcjonująca rodzina, rozumiana jako wspólnota osób, tworzy najlepsze warunki do rozwoju człowieka i urzeczywistniania jego człowieczeństwa" (Opozda, Parzyszek, 2019, s. 7). Szczególnym wyzwaniem jest wsparcie rodzinnej pieczy zastępczej, zwłaszcza podczas pandemii, co założono podkreślić w tej wypowiedzi, wskazując także wyniki działań i badań własnych.

\section{TROSKA O DZIECKO I JEGO OPIEKUNÓW}

\section{PODCZAS PANDEMII 2020 - 2021. WYBRANE ASPEKTY}

Szkoła z racji obowiązku edukacyjnego jest dla znacznej części społeczeństwa (uczniów) globalnym opiekunem organizującym środowisko ich życia. Jest ono ściśle powiązane z rodziną. Jednymi z pierwszych raportów na temat sytuacji dziecka w pandemii w szkole i w rodzinie w Polsce były: Ptaszek, Stunża, Py- 
żalski, Dębski, Bigaj, 2020; Makaruk, Włodarczyk, Szredzińska, 2020. Na jego podstawie oraz innych źródeł szczególnej uwagi wymagają takie zjawiska, jak: istnienie wielu dzieci, które nie uczestniczą w edukacji szkolnej, także zdalnej, nasilanie się osamotnienia dzieci, trudne godzenie pracy zawodowej rodziców realizowanej w domu i zdalnego nauczania dzieci, szczególnie przewlekle chorych i z niepełnosprawnościami, ograniczenia aktywności na świeżym powietrzu, wiele okazji do „życia po swojemu”, „życie w sferze on-line”, „życie z naginaniem prawa". Rozmowy ze studentami, często nauczycielami, pracownikami socjalnymi, pedagogami, wychowawcami, rodzicami oraz czytane wpisy na portalach społecznościowych pozwalają poznać skrajne przypadki opisanych w raportach zjawisk. Z oczywistych względów skupiają się one na dzieciach, a w mniejszym stopniu na ich opiekunach, szczególnie społecznych oraz ich wspieraniu i pomaganiu im systemowo. Przeprowadzenie pogłębionych refleksji w tych obszarach byłoby wskazane.

Obecnie (w czasie czwartej fali obostrzeń) publikowanych jest coraz więcej raportów. Wymienić warto np. dotyczący realizacji zadań asystenta rodziny w pandemii (Krasiejko, 2021), czy sytuacji dzieci z niepełnosprawnościami w czasie pandemii (Kocejko, 2021).

W okresie pandemii szczególnie ważnym elementem wspierającym rodzinę i szkołę mogły być placówki wsparcia dziennego. Na temat ich pracy, a raczej ich niedostatków, czy braku, raporty nie powstawały. Wiele z nich było zamkniętych, a kontakt wychowawców z dziećmi i ich rodzicami możliwy był tylko on-line. Lektura wpisów w grupach facebookowych pozwalała zauważyć bezradność kadry wobec takiej sytuacji, zbyt małe zainteresowanie rozwiązywaniem indywidualnych spraw, szukanie możliwych rozwiązań ocenianych niekiedy w kategorii mniejszego zła. Rozmowy ze studentami, znającymi sytuację placówek, ukazywały niepokojące zjawiska, które dotąd nie miały miejsca. Na temat szczegółowych sytuacji nadal nie wiele wiemy. Jestem w trakcie prowadzenia dokładniejszych badań sondażowych, skupiając się w nich głównie na wypowiedziach opiekunów-wychowawców. Powstała podczas pandemii zbyt duża niewydolność tego elementu systemu. $\mathrm{Na}$ szczęście wybrane placówki dla dzieci z niepełnosprawnościami funkcjonowały w sposób ciągły i w formie bezpośredniej, stacjonarnej.

$\mathrm{Na}$ temat sytuacji dziecka w pandemii w pieczy zastępczej (rodzinnej i instytucjonalnej) ogólnych, odrębnych raportów nie ma. Z opublikowanych najnowszych danych GUS podkreślenia wymaga zjawisko zmniejszenia liczby opiekunów (zarówno małżeństw jak i osób samotnych) w rodzinnej pieczy zastępczej w roku 2020 w porównaniu z rokiem 2019 (GUS, 2019, 2020). Szczegółowe zestawienie zamieszczono w tabeli 1 . 
Tabela 1. Porównanie liczby osób pełniących rolę opiekunów w rodzinnej pieczy zastępczej w roku 2019 i 2020

\begin{tabular}{|c|c|c|c|c|c|c|c|}
\hline $\begin{array}{l}\text { Osoby pełniące funkcje } \\
\text { opiekunów }\end{array}$ & \multicolumn{2}{|c|}{ Małżeństwa } & \multicolumn{2}{|c|}{ Osoby samotne } & \multicolumn{2}{|c|}{ Razem } & \multirow[t]{2}{*}{ Różnica } \\
\hline Rodzaje rodzinnej pieczy / Rok & $2019 \mathrm{r}$. & $2020 \mathrm{r}$. & $2019 \mathrm{r}$. & $2020 \mathrm{r}$. & $2019 \mathrm{r}$. & $2020 \mathrm{r}$. & \\
\hline Rodziny zastępcze & 19605 & 19190 & 16401 & 16665 & 36006 & 35855 & $\begin{array}{l}\text { Mniej } \\
\text { o } 151\end{array}$ \\
\hline Rodzinne domy dziecka & 585 & 588 & 81 & 97 & 666 & 685 & $\begin{array}{c}\text { Więcej } \\
\text { o } 19\end{array}$ \\
\hline Razem & 20190 & 19778 & 16482 & 16762 & 36672 & 36540 & $\begin{array}{l}\text { Mniej } \\
\text { o } 132\end{array}$ \\
\hline
\end{tabular}

Źródło: opracowanie własne na podstawie danych GUS.

Z danych w tabeli wynika, że w 2020 r. w rodzinnej pieczy zastępczej było o 132 opiekunów mniej niż w 2019 r. W rodzinach zastępczych nastąpiło zmniejszenie liczby małżeństw a wzrosła liczba osób samotnych. W rodzinnych domach dziecka nastąpił niewielki wzrost zatrudnionych małżeństw i większy osób samotnych. Dobrze byłoby dokładniej poznać przyczyny rezygnacji z roli opiekuna zastępczego. Z obserwacji własnych jedną z istotnych było przeciążenie i bezradność doświadczane podczas pandemii. Prezentowane w dalszej części artykułu wyniki badań własnych wynikają z chęci zapobiegania tym tendencjom oraz poznania gotowości studentów do zostania rodzicem zastępczym lub adopcyjnym oraz wspierania pieczy zastępczej.

Realizacja zadań pieczy zastępczej nie jest łatwa. Do niekorzystnych zjawisk Maria Kolankiewicz zaliczyła np. takie, jak: wypalenie emocjonalne opiekunów i zaprzestanie sprawowania opieki, rotacja dzieci pomiędzy różnymi formami pieczy zastępczej, nie zawsze dobra jakość opieki tworzona w każdej jej formie dla każdego dziecka, utrudnione usamodzielnienie podopiecznych, szczególnie chorych i z niepełnosprawnością, „dzieci w niewystarczająco dobrych rodzinach” (Kolankiewicz, 2020). Można założyć, że podczas pandemii one pogłębiały się i tworzyły „nową rzeczywistość”. Warto poznać, czy była ona trudniejszą, negatywną dla dzieci i ich opiekunów czy może stworzyła nowe pozytywne możliwości. Z badań Marzeny Ruszkowskiej na temat pieczy instytucjonalnej w pandemii wynika, że pozostawiono placówki same sobie bez dodatkowego wsparcia, realizowano zdalne nauczanie bez wsparcia placówek oświatowych i samych nauczycieli (Ruszkowska, 2020, s. 74). Lektura wpisów w grupach facebook, rozmowy ze studentami znającymi sytuację placówek pozwala stwierdzić, że nadal niewiele wiemy na omawiany temat. Badania własne sondażu pt. „Piecza zastępcza w pandemii w percepcji osób zaangażowanych w jej sprawowanie”, 
zrealizowanego od października do grudnia 2020, pozwalają autorce także na dalsze uogólnienia (Gajewska, 2021). Wybranymi, wskazanymi przez badanych, zmianami u podopiecznych we wszystkich rodzajach form pieczy w większości ocenione zostały negatywnie. W rodzinnej pieczy były to: „frustracja; dzieci częściej korzystają z telefonów i tabletów”; „złość związana z ograniczeniami”, „mniej możliwości kontaktowania się dzieci z dziadkami”. Z pozytywnych zmian: „więcej czasu spędzanego w gronie najbliższej rodziny” oraz ,integracja z rodziną”. W instytucjonalnej pieczy wskazano na: ,spadek motywacji do nauki - 2; niechęć do realizowania zdalnego nauczania; zmiany w zachowaniu; tęsknota za bezpośrednimi kontaktami z rodziną; dzieci przebywają stale w placówce -2 ; Tęsknota za rodziną". Wskazano najwięcej zmian pozytywnych. Osoby, pośrednio zaangażowane w sprawowanie pieczy zastępczej, podkreśliły przede wszystkim: „udziela się dodatkowy stres związany z ograniczeniami i swobodnymi wyjściami”. Pozytywną zaobserwowaną zmianą było: „większe wyciszenie u chłopca nadpobudliwego (pomaga w tym zdalne nauczanie - mniej okazji do konfliktów)" (Gajewska, 2021, s. 54-55).

Zdiagnozowanymi innymi negatywnymi zjawiskami były m.in.: brak dobrej pomocy w sytuacji zachorowania opiekunów w rodzinnej pieczy, zwiększająca się liczba dzieci zgłaszających się do instytucjonalnej pieczy na własną prośbę, konieczność pracy wychowawców w placówkach po kilkanaście godzin, kilkanaście dni, problemy ze zdalnym nauczaniem (Gajewska, 2021, s. 53-58).

Zjawiskami pozytywnymi $\mathrm{w}$ pieczy zastępczej były np.: większa integracja w rodzinnych i instytucjonalnych formach pieczy zastępczej (dzieci, dzieci i kadry, kadry), rozwój zachowań altruistycznych dzieci oraz ich opiekunów, społeczeństwa wobec instytucjonalnej pieczy zastępczej, zwiększenie zakresu niezależności, zasobu do radzenia sobie w zaistniałej sytuacji (Gajewska, 2021, s. 57).

Do niepokojących zjawisk zaliczyć można także: coraz częściej okazywane „wypalenie rodzicielskie”, zamknięte placówki wsparcia dziennego - kontakt on-line, kontakt on-line służb wspierających podopiecznych i ich rodziny, rezygnacje z pełnienia funkcji rodzin zastępczych, zbyt mało chętnych do bycia rodzicami zastępczymi, profesjonalizacja rodzinnej pieczy zastępczej stała się zagrożona, pozostawienie instytucjonalnej pieczy zastępczej bez wystarczającej pomocy i w atmosferze „do likwidacji”, wzrastająca liczba rozwodów, niedostateczne warunki do nauki i pracy zdalnej dzieci i rodziców, negatywne, kumulujące się zmiany u podopiecznych, wydłużanie decyzji w sprawach dzieci (por. Harewska, 2021, s. 248-252), brak dobrej komunikacji społecznej (por. Basiaga, Łukasik, 2020, s. 56).

Troszcząc się o dobro dziecka, szczególnie w pandemii i w pieczy zastępczej, wypada zastanowić się czy w konkretnych sytuacjach chodzi o niego, czy może 
bardziej o interesy - funkcjonowanie systemu pomocy, a może jeszcze o coś innego? Co jest ważniejsze? Może istotniejsze bywa dobro i efektywność systemu, mierzona wzrostem statystyk, liczbą rozwiązanych problemów w tych statystykach oczekiwanych? Kto broni, dba o dziecko? Komu na czym zależy? Czy są to dwa światy? Dlaczego tak jest? Dlaczego dziecko zmienia formy opieki - instytucje, rodziny? O co chodzi rodzinie zastępczej, a o co przedstawicielowi instytucji pomocy społecznej? Dla przykładu: dziecko w rodzinie zastępczej, mające trudności, w tym także psychiczne, wraz z opiekunem usamodzielnienia zmieniają decyzję w sprawie opuszczenia formy opieki. Dziecko nadal chce kontynuować naukę i pracować nad sobą. Służby społeczne z niepokojem patrzą na zaistniałą sytuację, która przede wszystkim zablokuje miejsce w rodzinie i niemożliwe będzie umieszczenie $\mathrm{w}$ niej kolejnego dziecka oraz poniesione zostaną koszty edukacji oraz leczenia.

Dobro dziecka powinno być celem każdego opiekuna oraz systemów tworzonych w celu objęcia dziecka pieczą, edukacją, pomocą. Czy zaistniałe w pandemii problemy wskazujące na trudności w tym zakresie rodziny, systemu pomocy społecznej, edukacji, zdrowia, sądownictwa są chwilowe? Dlaczego występują takie niedostatki w funkcjonowaniu systemowych rozwiązań, bezradność, dylematy etyczne, pogłębianie problemów u dzieci - podopiecznych, ich osamotnienie i opuszczenie? Poszukiwanie odpowiedzi na te i wiele innych pytań będą zapewne nadal nurtowały badaczy.

\section{GOTOWOŚĆ STUDENTÓW DO ZOSTANIA RODZICEM ZASTĘPCZYM \\ LUB ADOPCYJNYM, ICH WIEDZA I POSTRZEGANIE PIECZY ZASTĘPCZEJ. WYNIKI BADAŃ WŁASNYCH 2021 R. \\ W PORÓWNANIU Z 2009 R.}

\section{Metodologia badań}

Sondaż diagnostyczny zrealizowano z zastosowaniem autorskiej ankiety udostępnionej studentom i słuchaczom studiów podyplomowych Wydziału Nauk Społecznych Uniwersytetu Zielonogórskiego wszystkich lat i typów studiów poprzez test-quiz w systemie google classroom UZ. Kwestionariusz ankiety pt. „Adopcja, rodziny zastępcze, piecza zastępcza w wypowiedziach społeczności akademickiej Uniwersytetu Zielonogórskiego - badanie 2020" jest rozwinięciem jego wersji z roku 2006 opublikowanego w 2009 roku (Gajewska, 2009c, s. 97). Z tych szerokich badań wybrano kilka wątków dotyczących tematu artykułu.

Celem poznawczym uczyniono zdiagnozowanie deklarowanej gotowości przyszłych pedagogów do założenia rodziny zastępczej i adopcyjnej podczas pandemii 
COVID-19, jej wybranych uwarunkowań oraz poglądów na temat zapotrzebowania w społeczeństwie na rodziny zastępcze i adopcyjne oraz wybranych elementów wiedzy na temat pieczy zastępczej w Polsce, a także ich porównanie z wynikami opublikowanymi w roku 2009.

Celem praktycznym było zainteresowanie studentów zjawiskiem pieczy zastępczej, zmotywowanie do zapoznania się z tą tematyką oraz uświadomienie im własnej gotowości do podjęcia się roli opiekunów zastępczych i adopcyjnych, a także profesjonalnej pomocy takim opiekunom podczas przyszłej lub aktualnej pracy zawodowej.

Dla realizacji celu poznawczego sformułowano trzy globalne problemy badawcze: pierwszy dotyczący rodzin zastępczych i porównania wyników z lat 2021 i 2009; drugi dotyczący rodzin adopcyjnych oraz trzeci odnoszący się do wybranych elementów wiedzy na temat pieczy zastępczej w Polsce.

\section{Charakterystyka badanych}

Ankietę wypełniło 121 osób. Kobiety stanowiły 90,1\% badanych, mężczyźni 9,9\%. Respondenci mieszkali w województwach: głównie lubuskim, a także dolnośląskim, zachodniopomorskim i wielkopolskim.

\section{Organizacja i przebieg badań}

Ankieta została udostępniona z prośbą o wypełnienie w grudniu 2020 r. na początku lub przed pierwszymi zajęciami z tego zakresu. Badanie zakończono 31 marca $2021 \mathrm{r}$.

\section{Wyniki badań własnych}

Prezentowane wyniki ze względu na ograniczone ramy tego artykułu stanowią część całości zgromadzonych danych.

1. Deklarowana gotowość do zalożenia rodziny zastępczej, jej wybrane uwarunkowania, pogląd na zapotrzebowanie spoleczne na nie i wiedza na temat rodzin zastępczych w 2021 roku w porównaniu z 2009 rokiem.

Deklarowana gotowość do założenia w przyszłości rodziny zastępczej - wyniki sondażu z 2021 r. w porównaniu z 2009 r.

W 2021 r. 8,3\% ze 121 ankietowanych zdeklarowało zdecydowaną chęć założenia w przyszłości rodziny zastępczej. Natomiast $24,8 \%$ odpowiedziało, że raczej tak. Tym samym 33,1\% z nich było pozytywnie nastawionymi do podjęcia się takiego zadania. Blisko $6 \%$ zdecydowanie nie zdeklarowało takiej gotowości. Ale aż 35,5\% wskazało odpowiedź „nie wiem”. Nie przyjęło więc negatywnego 
stanowiska, co wydaje się ważne o tyle, że można próbować ich przekonywać i tym samym poszerzać grupę skłonnych do zostania rodzicem zastępczym.

W 2009 r. 5,43\% z 405 badanych sądziło, że w przyszłości byłoby zdecydowanie chętnymi założyć rodzinę zastępczą. Kolejne $28,15 \%$ odpowiedziało, że raczej tak. Oznacza to, że 33,55\% z nich było pozytywnie nastawionymi do podjęcia się takiego zadania. Jedynie $2,22 \%$ jeszcze nie wiedziało, jaką podejmie decyzję (Gajewska, 2009c, s. 112).

$\mathrm{W}$ tabeli 2 zostało przedstawione zestawienie wyników z obu sondaży oraz tendencje wynikające $\mathrm{z}$ ich porównania.

Tabela 2. Deklarowana gotowość do założenia w przyszłości rodziny zastępczej - wyniki sondażu 2021 r. w porównaniu z 2009 r. w \%.

\begin{tabular}{|l|c|c|c|}
\hline $\begin{array}{l}\text { Kategorie deklarowanej } \\
\text { gotowości }\end{array}$ & $2021 \mathrm{r}$. & $2009 \mathrm{r}$. & $\begin{array}{c}\text { Tendencja wynikająca } \\
\text { z różnicy między 2021 r. a 2009 r. }\end{array}$ \\
\hline 1. Nie wiem & 35,50 & 2,22 & Znaczący wzrost o 33,28 punktów procentowych \\
\hline 2. Zdecydowanie nie & 5,80 & 12,84 & Spadek o 7,04 punktów procentowych \\
\hline 3. Raczej nie & 25,60 & 51,36 & Znaczący spadek o 25,76 punktów procentowych \\
\hline 4. Raczej tak & 24,80 & 28,15 & Niewielki spadek o 3,35 punktów procentowych \\
\hline 5. Zdecydowanie tak & 8,30 & 5,43 & Wzrost o 2,87 punktów procentowych \\
\hline
\end{tabular}

Źródło: obliczenia własne.

Dane zamieszczone w tabeli wskazują na różnice, które najbardziej są widoczne w kategorii odpowiedzi „nie wiem” oraz „raczej nie”. W porównaniu z sondażem sprzed 12 lat można to traktować jako potencjał społeczny, jako efekt zmian, które w tym czasie się dokonały. Zastanawiające jest czy zdiagnozowana gotowość jest związana z coraz liczniejszymi kampaniami społecznymi na rzecz rodzinnej pieczy zastępczej, czy może obserwacjami osób, które chciałyby podjąć się roli rodzica zastępczego oraz ocenami tych, którzy nimi już są. W badanej, specyficznej grupie ok. 1/3 osób jest pozytywnie nastawiona do zadania, a w zasadzie, jeżeli ktoś deklaruje odpowiedź „,raczej nie” lub „nie wiem” także można to ocenić z nadzieją na jego otwartość.

Diagnozowana gotowość do założenia rodziny zastępczej może być wyznaczana przez różne czynniki. W 2009 r. ustalono, że jednym z nich jest płeć. W prezentowanym sondażu w $2021 \mathrm{r}$. taka analiza nie jest możliwa ze względu na zbyt mały udział mężczyzn w badaniu. Zaprezentowano natomiast w kolejnych akapitach wyniki dotyczące znajomości przez badanych osób, które chciałyby oraz założyły rodzinę zastępczą, a także ocenę tej decyzji. 
Znajomość przez badanych osób, które chciałyby założyć rodzinę zastępczą 2009 r. i 2021 r.

Przyjmując założenie, że jeżeli znamy kogoś, kto chciałby założyć rodzinę zastępczą, może to mieć wpływ na deklaracje innych, ciekawe mogą być uzyskane na ten temat odpowiedzi. W 2009 r. 17\% badanych znało kogoś kto chciałby założyć rodzinę zastępczą (Gajewska, 2009c, s. 157). W 2021 r. takich osób było 26,4\%. Oznacza to wzrost liczby tych, którzy zetknęli się z opisywaną formą opieki.

\section{Znajomość osób, które założyły rodzinę zastępczą 2009 r. i 2021 r.}

W 2009 r. 41,73\% badanych znało kogoś, kto założył rodzinę zastępczą, w 2021 r. ponad połowa diagnozowanych, tj. 51,2\%. Jest to wzrost o 9,47 punktów procentowych. Można się zastanawiać co w większym stopniu sprzyja budowaniu gotowości studentów do podjęcia się roli rodzica zastępczego - obserwacje osób, które chcą czy które założyły takie rodziny. W obu pomiarach tych drugich było niemal dwukrotnie więcej.

Ocena decyzji o założeniu rodziny zastępczej przez znajome osoby w opinii ankietowanych 2009 r. i 2021 r.

W 2009 r. 72,193\% badanych oceniło zdecydowanie pozytywnie decyzję o założeniu rodziny zastępczej przez znane im osoby, a 21,925\% raczej pozytywnie (Gajewska, 2009c, s. 159). W 2021 r. zdecydowanie pozytywnych opinii było $67,5 \%$ i raczej pozytywnych $30 \%$.

Deklarowana gotowość do założenia rodziny zastępczej a znajomość osób, które taką rodziną już są

W tabeli 3 zaprezentowano wyniki dotyczące deklarowanej gotowości do założenia rodziny zastępczej zróżnicowane według tego czy badani znali osobę, która założyła rodzinę zastępczą. Niestety tych danych nie można było zestawić statystycznie z wynikami z 2009 r.

Analizując dane w tabeli warto wyeksponować tendencję wskazującą, że pozytywna deklaracja gotowości do zostania w przyszłości rodzicem zastępczym jest większa u badanych, którzy znali osoby, które założyły już rodzinę zastępczą. Ciekawe byłoby prześledzenie zgromadzonych wyjaśnień podjętych deklaracji. Będą one stanowiły ważny element kolejnego opracowania na ten temat. Mogą one stanowić dodatkowe potwierdzenie słuszności realizowanego w różnych formach pieczy zastępczej studenckiego wolontariatu i innych działań ukazujących obiektywny ich obraz. 
Tabela 3. Deklarowana gotowość badanych do założenia rodziny zastępczej w pandemii a znajomość osób, które założyły rodzinę zastępczą

\begin{tabular}{|l|c|c|c|c|c|c|}
\hline Znajomość osób, które założyły rodzinę zastępczą & \multicolumn{2}{|c|}{ Nie } & \multicolumn{2}{c|}{ Tak } & \multicolumn{2}{c|}{ Razem } \\
\hline Kategorie deklarowanej gotowości & $\mathrm{N}$ & $\%$ & $\mathrm{~N}$ & $\%$ & $\mathrm{~N}$ & $\%$ \\
\hline 1. Nie wiem & 23 & $53 \%$ & 20 & $47 \%$ & 43 & $36 \%$ \\
\hline 2. Zdecydowanie nie & 4 & $57 \%$ & 3 & $43 \%$ & 7 & $6 \%$ \\
\hline 3. Raczej nie & 17 & $53 \%$ & 15 & $47 \%$ & 32 & $26 \%$ \\
\hline 4. Raczej tak & 12 & $41 \%$ & 17 & $59 \%$ & 29 & $24 \%$ \\
\hline 5. Zdecydowanie tak & 3 & $30 \%$ & 7 & $70 \%$ & 10 & $8 \%$ \\
\hline
\end{tabular}

Źródło: obliczenia własne.

\section{Adopcja}

\section{Deklarowana gotowość do zalożenia rodziny adopcyjnej 2021 r.}

W 2021 r. 9,9\% ze 121 badanych sądziło, że w przyszłości byłoby zdecydowanie chętnymi założyć rodzinę adopcyjną. Kolejne 26,4\% odpowiedziało, że raczej tak. Oznacza to, że $36,3 \%$ z nich było pozytywnie nastawionymi do podjęcia się takiego zadania. Aż 32,2\% jeszcze nie wiedziało, jaką podejmie decyzję. Tylko kilka osób wyraziło swój zdecydowany sprzeciw takiemu zadaniu.

\section{Znajomość przez badanych osób, które chciałyby założyć rodzinę adopcyjną 2021 r.}

Blisko jedna czwarta badanych - $24 \%$ znała kogoś, kto chciałby założyć rodzinę adopcyjną. Jednak $76 \%$ nie miało takiej okazji.

\section{Znajomość osób, które założyły rodzinę adopcyjną 2021 r.}

Blisko połowa badanych (47,9\%) znała osoby, które założyły rodzinę adopcyjną. Oceniam tę informację bardzo pozytywnie, wręcz niesamowicie. Zakres tego zjawiska jest duży. 52,1\% nie miało takiego doświadczenia. Warto więc stworzyć taką okazję. Ciekawe jest jakie oceny tych decyzji sformułują.

\section{Ocena decyzji o założeniu rodziny adopcyjnej przez znajome osoby w opinii ankietowanych 2021 r.}

Zdecydowanie pozytywnie oceniło decyzję o założeniu rodziny adopcyjnej znanych osób 54,9\% badanych z 102, którzy zdeklarowali taką znajomość. Kolejne $42,2 \%$ uznało ją za raczej pozytywną. Pozostali (3,9\%) negatywnie ocenili tę decyzję. 


\section{Przeświadczenie badanych o tym, czy rodziny zastępcze i adopcyjne są po- trzebne}

W 2021 r. 86,8\% badanych uważało, że rodziny zastępcze są zdecydowanie potrzebne, kolejne $12,4 \%$ stwierdziło, że raczej tak. Zatem aż 99,2\% zauważało uzasadnienie dla ich tworzenia. Wynik można uznać za wysoko sprzyjający wyjaśnianemu zjawisku.

Dla porównania w 2009 r. uzyskano podobny wynik. Dokładniej osoby, które uważały, że rodziny zastępcze są zdecydowanie potrzebne, stanowiły $83,5 \%$ badanych, raczej tak $15,8 \%$, raczej nie $0,2 \%$ oraz $0,5 \%$ inne, które są raczej pozytywne (Gajewska, 2009c, s. 128).

Jeżeli chodzi o oceny ankietowanych w $2021 \mathrm{r}$. dotyczące tego czy rodziny adopcyjne ich zdaniem są potrzebne $-82,6 \%$ wskazało, że zdecydowanie tak, a $17,4 \%$ raczej tak.

\section{POSIADANIE WIEDZY O WYBRANYCH ELEMENTACH SYSTEMU PIECZY ZASTĘPCZEJ W POLSCE}

Poszukując odpowiedzi na pytanie czy badani potrafią prawidłowo wskazać, która instytucja nie należy do instytucjonalnej pieczy zastępczej można się zorientować na ile znają aktualnie istniejące formy opieki społecznej. Prawidłowej odpowiedzi, czyli wskazanie na rodzinny dom dziecka, udzieliło $28,1 \%$ badanych, co stanowiło trochę ponad jedną piątą grupy. Najwięcej osób 50,4\% wskazało na specjalistyczno-terapeutyczną regionalną placówkę opiekuńczo-terapeutyczną, i po $10,7 \%$ na interwencyjny ośrodek preadopcyjny oraz placówkę opiekuńczo-wychowawczą.

Kolejne pytanie: czy w myśl polskiego prawa adopcja jest rodziną zastępczą? - miało na celu uzyskanie informacji na temat posiadanej przez badanych wiedzy pozwalającej rozróżnić adopcję i rodzinę zastępczą. Odpowiedzi „nie” - prawidłowej - udzieliło 61,1\% ankietowanych, 19,8\% utożsamiło ze sobą te dwie różne formy opieki, a kolejne 19\% nie wiedziało jak jest. Między adopcją a rodziną zastępczą istnieją znaczące różnice. Wnioskiem jest konieczność ich wskazywania i wyjaśniania.

Ośrodek adopcyjny jest instytucją w systemie pomocy społecznej, który pełni specyficzne i bardzo ważne zadania na rzecz pieczy zastępczej. Trzeba jednak wiedzieć jaka jest to rola. Poproszono więc badanych o dokończenie zdania: ośrodek adopcyjny jest to... Można było wskazać na podpowiedzi lub wpisać własną odpowiedź. Najwięcej osób $43,8 \%$ wskazało, że jest to instytucja doradcza dla rodziców, trochę mniej $(38,8 \%)$, że jest to instytucja opiekuńczo-wychowawcza 
i 11,6\% instytucja dla dzieci. Nie wiedziało jak jest 2,5\% ankietowanych. Jedna osoba $(0,8 \%)$ napisała, że jest to instytucja, która prowadzi działalność konsultacyjną mającą na celu szkolenie osób, które pragną zostać rodziną adopcyjną, kolejne wskazanie było podobne: „instytucja zajmująca się pozyskiwaniem osób chętnych do tego, by zostać rodzicami adopcyjnymi”, następne także: „instytucja kwalifikująca rodziców adopcyjnych oraz dzieci wolne prawnie” oraz „instytucja prowadząca działalność konsultacyjną, mającą na celu szkolenie osób pragnących przysposobić dziecko".

Założono także zweryfikowanie tego czy badani wiedzą i potrafią wskazać, których rodzin zastępczych jest $\mathrm{w}$ Polsce najwięcej? Na rodziny spokrewnione wskazało $59,5 \%$ badanych, na zawodowe - pełniące funkcje pogotowia rodzinnego $19 \%$, na niezawodowe $12,4 \%$, na zawodowe specjalistyczne $6,6 \%$ oraz na zawodowe bez wskazanych zadań $2,5 \%$.

W większości z badanych grup starano się po wypełnieniu ankiety omówić uzyskane odpowiedzi i wskazać na prawidłowe odsyłając słuchaczy do źródeł na ten temat. Głównie jest to Ustawa o wspieraniu rodziny i systemie pieczy zastępczej (Ustawa z dnia 9 czerwca 2011 r.).

\section{UOGÓLNIENIA I WNIOSKI Z BADAŃ WŁASNYCH - DYSKUSJA}

Zaprezentowane, wybrane wyniki badań własnych, zgromadzone podczas pandemii COVID-19, pozwalają sformułować następujące najważniejsze uogólnienia i wnioski:

- około jedna trzecia studentów, zarówno w sondażu przeprowadzonym podczas pandemii jak również w 2009 r. zdeklarowała swoją gotowość do zostania rodzicem zastępczym. W 2021 roku zdiagnozowaną różnicą w stosunku do 2009 roku był znaczący wzrost liczby osób, które wskazały odpowiedź „nie wiem” o 33,28 punktów procentowych;

- 36,3\% badanych zadeklarowało swoje większe lub mniejsze zdecydowanie do założenia rodziny adopcyjnej. Wynik ten może zadowalać, chociaż warto podejmować dalsze działania, które spowodują wzrost osób z gotowością do zostania taką rodziną. Mając możliwość porównania z ustaleniami A. Kwaśnik w grupie 100 studentów w 2015 roku można się zastanawiać z czego wynika inny wynik. Autorka przeprowadziła badania w grupie po równo zróżnicowanej pod względem płci i studiowanych kierunków (po 50\% pedagogiki i nauk ścisłych). $47 \%$ z nich wyraziło swoją gotowość do założenia rodziny adopcyjnej, $8 \%$ było przeciwnego zdania, a 45\% jeszcze nie wiedziało (Kwaśnik, 2015, s. 86); 
- więcej było wśród badanych tych, którzy zadeklarowali chęć założenia rodziny adopcyjnej niż zastępczej. Biorąc pod uwagę podobny stopień procentowy dla odpowiedzi „nie wiem” (36,3\% dotyczący adopcji i 35,5\% rodziny zastępczej) warto rozważyć co jest tego przyczyną. Analiza uzasadnień wypowiedzi będzie podjęta $\mathrm{w}$ przyszłości;

- w sondażu 2021 r. trochę ponad $26 \%$ badanych znało osoby, które chciałyby założyć rodzinę zastępczą oraz $51 \%$ znało taką, która już ją założyła. W jednym i drugim przypadku było ich więcej niż w sondażu z 2009 r. Wychodząc z założenia, że znajomość takich rodziców może mieć wpływ na decyzje innych oraz że nadal jest sporo takich przyszłych pedagogów, nauczycieli, którzy nie zetknęli się z nimi, może warto studentów, którzy nie mieli takiej okazji, wprowadzać w sytuacje, które im to umożliwią. Warto też dodać, na podstawie doświadczeń własnych, że od kilku lat studenci coraz częściej mówią otwarcie o tym, że byli podopiecznymi rodzin zastępczych, adopcyjnych, rodzinnych domów dziecka czy instytucjonalnych form, co także stanowi okazję do naturalnych rozmów w grupach, realizujących wskazany cel. Coraz częściej także podejmują się oni wolontariatu w rodzinnej i instytucjonalnej pieczy zastępczej (Gajewska, 2009a, s. 416-420, Gajewska, 2009c, Wojtowicz, 2018);

- powyższy wniosek wzmacniać może także to, że badane osoby znające osoby, które założyły rodziny zastępcze w 97,5\% w roku 2021 i 94,1\% w roku 2009, oceniły tę decyzję zdecydowanie i raczej pozytywnie;

- 99,2\% badanych uważało, że rodziny zastępcze są potrzebne oraz $100 \%$ uznało, że rodziny adopcyjne są potrzebne;

- nadal należy podnosić poziom wiedzy kandydatów do zawodów pedagogicznych, nauczycielskich na temat pieczy zastępczej i adopcji. $28 \%$ badanych prawidłowo wskazało na rodzinną formę pieczy zastępczej spośród rodzajów opieki instytucjonalnej. 61\% rozróżniało rodzinę zastępczą od adopcyjnej, blisko $20 \%$ uważało, że są to takie same formy opieki, a kolejne prawie $19 \%$ nie miało na ten temat wiedzy. Trochę ponad $40 \%$ badanych nie wiedziało, których rodzin zastępczych jest w Polsce najwięcej. Ponad połowa badanych nie wiedziała jaką instytucją jest i jaką rolę spełnia ośrodek adopcyjny.

Porównanie wyników z czasu pandemii 2020 r. z tymi z 2009 r. może utwierdzać w przekonaniu, że warto kontynuować obiektywną prezentację wśród studentów - kandydatów na profesjonalistów, którzy w przyszłości mogą współpracować z dziećmi i ich opiekunami, poszerzanie ich wiedzy na ten często nie eksponowany i niezrozumiały temat, a także ich kompetencje i umiejętności optymalnego postępowania w praktyce. Pożądane są także wnikliwie prowadzone badania na temat pieczy zastępczej, nie tylko ilościowe, ale jakościowe. Cenne może być ich upublicznianie. 
Przeprowadzenie badań pozwoliło zrealizować także cel praktyczny. Miało to wyraz w wielu formach. Po wypełnieniu kwestionariusza zwiększała się liczba precyzyjnie formułowanych pytań przez studentów. Coraz liczniej brali oni udział w spotkaniach on-line organizowanych przeze mnie z różnymi specjalistami realizującymi zadania pieczy zastępczej. Zwiększyła się liczba studentów, którzy podjęli się roli wolontariuszy w różnych formach tej opieki. Wzrosło zainteresowanie prowadzeniem badań naukowych na wskazany temat zarówno ze mną pozadydaktycznie, jak również $\mathrm{w}$ ramach prac dyplomowych.

\section{ZAKOŃCZENIE}

Nie znane są jeszcze wszystkie negatywne skutki społeczne pandemii 2020/2021 dotyczące opieki nad dzieckiem, wsparcia rodziny i pieczy zastępczej. Przytoczone wyniki - w nawiązaniu do wiedzy na temat badanych zjawisk - wskazują, że mogą być one bardzo odczuwalne. Dlatego tak ważny jest społeczny potencjał ludzie rozumiejący i przychylnie oceniający funkcjonowanie pieczy zastępczej, troski o dzieci i ich opiekunów oraz deklarujących gotowość do założenia rodzin zastępczych i adopcyjnych, realizowany wolontariat w pieczy zastępczej, kampanie informacyjne, które dobrze byłoby wspierać. W funkcjonowaniu pieczy zastępczej nad dzieckiem nadal jest wiele barier, na jej temat „żywe” są stereotypy i mity społeczne, a objętych nią dzieci jest dużo (GUS, 2021, s. 1).

Przeprowadzone badania własne, których częściowe wyniki zostały zaprezentowane w tym artykule, ukazują sprzyjające tendencje, które się dokonują na przestrzeni lat 2009-2021 (np. wyższą gotowość do pełnienia ról opiekunów zastępczych). Z drugiej strony jednak nadal nie przekłada się to na zwiększenie liczby rodzin adopcyjnych, zastępczych i możliwość likwidacji w Polsce pieczy instytucjonalnej. Ciągle zapotrzebowanie społeczne na rodzinną pieczę zastępczą jest duże. Pandemia natomiast, która nadal trwa, mocno komplikuje osiągnięcie tego celu. Powstaje zmodyfikowana rzeczywistość społeczna, w tym, co ważne, pomocy społecznej, edukacyjna, czy sąsiedzka, która zwiększa konieczność troszczenia się o dzieci, ale także inaczej, a może intensywniej o ich opiekunów. Ich wypalenie rodzicielskie/zawodowe zbyt często powoduje rezygnację z podjętego zadania „opiekuna społecznego”. Wypada też podkreślić konieczność stworzenia profesjonalnego systemu pozyskiwania osób chętnych do podjęcia się opieki zastępczej, na co wskazywała wiele lat temu Marzena Ruszkowska (Ruszkowska, 2013, s. 91). 


\section{BIBLIOGRAFIA}

Basiaga, J., ŁukasiK, I. (2020). Kompetencje społeczne zawodowych rodziców zastępczych. Problemy Opiekuńczo-Wychowawcze, 10, 44-58. DOI: 10.5604/01.3001.0014.4253.

Blasiak, A., Pasierbek, W. (2020). Edytorial: W trosce o człowieka. Horyzonty Wychowania, 19(52), 5-6.

Gajewska, G.G. (2021). Piecza zastępcza w pandemii w percepcji osób zaangażowanych w jej sprawowanie. Horyzonty Wychowania. 20(53), 49-60. DOI: 10.35765/hw.1523.

Gajewska, G.G. (2020). Współczesne tendencje, problemy oraz wyzwania w opiece $i$ wychowaniu. Teoria, metodyka i praktyka w opinii studentów. Kraków: OW „Impuls”.

Gajewska, G. (2009a). Wsparcie dziecka w rozwoju. Konteksty opieki i edukacji. Zielona Góra: Oficyna Wydawnicza Uniwersytetu Zielonogórskiego.

Gajewska, G. (2009b). Pedagogika opiekuńcza. Elementy metodyki. Zielona Góra: PEKW „Gaja”.

GajewsKa, G. (2009c). Rodzinna opieka zastępcza. Z perspektywy województwa lubuskiego. Zielona Góra: Urząd Marszałkowski Województwa Lubuskiego. Departament Polityki Społecznej - Regionalne Centrum Animacji Kultury.

GajewsKa, G. (2006). O profesjonalizacji rodziców zastępczych. Problemy Opiekuńczo-Wychowawcze, 9, 19-24.

GUS. Piecza zastępcza w 2019 r. (14.05.2020r.). Pobrane 21.11.2020, https://stat.gov.pl/obszary-tematyczne/dzieci-i-rodzina/dzieci/piecza-zastepcza-w-2019-roku,1,4.html.

GUS. Piecza zastępcza w 2020 r. (13.05.2021r.). Pobrane 29.07.2021, https://stat.gov.pl/files/gfx/ portalinformacyjny/pl/defaultaktualnosci/6000/1/5/1/piecza_zastepcza_w_2020_r.pdf

Harewska, N. (2016). Szanse i bariery w profesjonalizacji opiekunów zastępczych. Problemy Opiekuńczo-Wychowawcze, 5, 17-24.

Harewska, N. (2021). Profesjonalizacja w rodzinnej pieczy zastępczej. Niepublikowana praca doktorska napisana pod kierunkiem dr hab. Grażyny Gajewskiej, prof. UZ i promotora pomocniczego dr Elżbiety Turskiej. Zielona Góra: Uniwersytet Zielonogórski.

Kocejкo, M. (2021). Sytuacja dzieci z niepełnosprawnościami w czasie pandemii COVID-19 - analiza intersekcjonalna. Dziecko Krzywdzone. Teoria, badania, praktyka, 20(2), 76-91.

Kolankiewicz, M. (2020). Zasady systemu pieczy zastępczej - dylematy praktyki. Problemy Opiekuńczo-Wychowawcze, 8, 29-43. DOI: 10.5604/01.3001.0014.4252.

KotARBIŃSKI, T. (1976). Medytacje o życiu godziwym. Warszawa.

KrasiejKo, I. (2021). Między wsparciem rodziny a ochroną dziecka przed krzywdzeniem - rola i zadania asystenta rodziny w czasie pandemii w kontekście działań innych zawodów pomocowych. Dziecko Krzywdzone. Teoria, badania, praktyka, 20(2), 13-37.

KWAŚNIK, A. (2015). Spoleczne postrzeganie adopcji przez studentów 1 roku studiów niestacjonarnych II stopnia. Na przykładzie kierunków ścisłych oraz pedagogiki Uniwersytetu Zielonogórskiego. Niepublikowana praca magisterska napisana pod kierunkiem dr hab. Grażyny Gajewskiej, prof. UZ. Zielona Góra: Archiwum Uniwersytetu Zielonogórskiego.

Makaruk, K., WŁodarczyk, J., SzredzińSka, R. (2020). Negatywne doświadczenia młodzieży $w$ trakcie Pandemii. Raport z badań ilościowych. Warszawa: Fundacja Dajemy Dzieciom Siłę.

Opozda, D., Parzyszek, M. (2019). Wstęp. W: D. Opozda, M. Parzyszek. Wychowanie w rodzinie $w$ wybranych zagadnieniach pedagogicznych. Pedagogika rodziny $w$ teorii i praktyce. T. 7. Prace 
Wydziału Nauk Społecznych 187. Lublin: Towarzystwo Naukowe Katolickiego Uniwersytetu Lubelskiego Jana Pawła II.

Ptaszek, G., Stunża, G.D., Pyżalski, J., DęBSki, M., Bigaj, M. (2020). Edukacja zdalna: co stało się z uczniami, ich rodzicami i nauczycielami? Gdańsk: Gdańskie Wydawnictwo Psychologiczne.

Raport z badań UNICEF (7 września 2020 r.). Co najmniej 1/3 uczniów na świecie nie ma dostępu do nauki zdalnej podczas zamknięcia szkót z powodu COVID-19. Pobrano 8.10.2020, https:// unicef.pl/co-robimy/aktualnosci/wiadomosci/raport-unicef-co-najmniej-1-3-uczniow-na-swiecie-nie-ma-dostepu-do-nauki-zdalnej-podczas-zamkniecia-szkol-z-powodu-covid-19.

Ruszkowska, M. (2020). Funkcjonowanie placówek opiekuńczo-wychowawczych w czasie pandemii. Problemy Opiekuńczo-Wychowawcze, 10, 67-75. DOI: 10.5604/01.3001.0014.5974.

Słownik synonimów języka polskiego, pobrano 9.04.2021, https://synonim.net/inaczej-troska+o+kogoś.

RuszkowsKa, M. (2013). Rodzina zastępcza jako środowisko opiekuńczo-wychowawcze. Warszawa: Centrum Rozwoju Zasobów Ludzkich.

Ustawa z dnia 9 czerwca 2011 r. o wspieraniu rodziny i systemie pieczy zastępczej. Dz.U. z 2011 r., poz. 998 , http://prawo.sejm.gov.pl/isap.nsf/DocDetails.xsp?id= WDU20111490887.

Wielki słownik języka polskiego, pobrano 9.04.2021, https://wsjp.pl/index.php?id_hasla=857\&id_ znaczenia $=4028520 \& 1=5$.

Wojtowicz, S. (2018). Rola wolontariatu w uzyskaniu samodzielności dzieci w rodzinach zastępczych. Niepublikowana praca magisterska napisana pod kierunkiem dr hab. Grażyny Gajewskiej, prof. UZ. Zielona Góra: Archiwum Uniwersytetu Zielonogórskiego.

\section{TROSKA O DZIECKO TROSKĄ O JEGO OPIEKUNÓW. \\ PIECZA ZASTĘPCZA I ADOPCJA W WARUNKACH PANDEMII. PORÓWNANIE WYNIKÓW SONDAŻY 2021 I 2009}

\section{STRESZCZENIE}

W artykule skupiono uwagę na problematyce troski o dziecko i jego opiekunów w warunkach trwającej pandemii. Podjęto próbę przedstawienia stanu wiedzy na temat pieczy zastępczej i adopcji oraz rozwiązań systemowych w tym czasie. Wskazano niepokojące i pozytywne zdiagnozowane zjawiska, które zaistniały podczas pandemii koronawirusa oraz kierunki do dalszych analiz. Zaprezentowano dotąd niepublikowane wyniki autorskich badań przeprowadzonych wśród studentów - przyszłych opiekunów. Część z nich porównano z wynikami z roku 2009. Założono ustalenie dokonujących się zmian w pieczy zastępczej. Zwrócono uwagę na: jak najlepsze przygotowanie profesjonalistów i społeczeństwa do rozumienia i realizowania rodzicielstwa zastępczego i adopcyjnego, wsparcia funkcjonowania pieczy zastępczej, a przede wszystkim gotowości do zostania rodzicem zastępczym i adopcyjnym.

Słowa kluczowe: troska o dziecko; troska o opiekunów dziecka; piecza zastępcza i adopcja w pandemii; gotowość studentów do założenia rodziny zastępczej i adopcyjnej, percepcja pieczy zastępczej i adopcji u studentów - przyszłych profesjonalistów. 


\title{
CARING FOR THE CHILD AS CARING FOR ITS CARERS. FOSTER CARE AND ADOPTION IN A PANDEMIC SETTING. COMPARISON OF THE RESULTS OF THE 2021 AND 2009 SURVEYS
}

\begin{abstract}
SUMMARY
The article focuses on the care of the child and its carers in the conditions of the ongoing pandemic. An attempt has been made to present the state of knowledge about family care, adoption and systemic actions during that time. Alarming and positive phenomena during the coronavirus pandemic are pointed out, as well as directions for further analyses. So far unpublished results of original research carried out among students - future carers - are presented. Some of them are compared with the results from 2009. It is assumed to establish the ongoing trends of changes in foster care. Particular attention is paid to the best possible preparation of professionals and society to understand and implement foster and adoption, support for the operation of foster care and, above all, to students' willingness to become foster or adoptive parents.
\end{abstract}

Keywords: care for a child; care for the child's guardians; foster care and adoption in pandemic; students' readiness to start a foster and adoptive family; perception of foster care and adoption among students - future professionals. 